\title{
Disorder and fluctuations in complex physical systems: Nobel Prize winner in physics 2021 Giorgio Parisi
}

\author{
Vyacheslav M. Tyutyunnik $\bowtie$ \\ Tambov State Technical University, 106, Sovetskaya St., Tambov 392000, Russian Federation, \\ International Nobel Information Centre (INIC), 30-6, Pervomaiskaya Sq., Tambov 392002, Russian Federation
}

$\bowtie$ vmtyutyunnik@gmail.com

\begin{abstract}
In 2021, the Nobel Prize in Physics was awarded "for innovative contributions to our understanding of complex systems," with half awarded jointly to Shukuro Manabe and Klaus Hasselmann "for the physical modelling of Earth's climate, quantifying variability and reliably predicting global warming", and the other half to Giorgio Parisi "for the discovery of the interplay of disorder and fluctuations in physical systems from atomic to planetary scales". Parisi discovered hidden patterns in disordered, complex materials. His discoveries are one of the most important contributions to the theory of complex systems. He proved that equilibrium is never achieved in spin glasses, because frustrations do not allow all limitations to be satisfied. In reality, there are an infinite number of practically equilibrium states in which frustrations tend to a minimum. Parisi's research interests cover 14 different directions.
\end{abstract}

Keywords: complex physical systems; interaction of disorder and fluctuations; Nobel Prize winner in physics 2021 Giorgio Parisi.

For citation: Tyutyunnik VM. Disorder and fluctuations in complex physical systems: Nobel Prize winner in physics 2021 Giorgio Parisi. Journal of Advanced Materials and Technologies. 2021;6(4):243-246. DOI: 10.17277/jamt. 2021.04.pp.243-246

\section{Беспорядок и флуктуации в сложных физических системах: лауреат Нобелевской премии по физике 2021 года Джорджо Паризи}

\author{
В. М. Тютюнник \\ Тамбовский государственный технический университет, \\ ул. Советская, 106, Тамбов 392000, Российская Федераиия, \\ Международный Информачионный Нобелевский Центр (МИНЦ), \\ Первомайская площадь, 30-6, Тамбов 392002, Российская Федераџия \\ $\triangle$ vmtyutyunnik@gmail.com
}

\begin{abstract}
Аннотация: В 2021 году Нобелевская премия по физике присуждена «за новаторский вклад в наше понимание сложных систем», причем половина присуждена совместно Сюкуро Манабе и Клаусу Хассельманну «за физическое моделирование климата Земли, количественную оценку изменчивости и надежное прогнозирование глобального потепления», а другая половина Джорджо Паризи «за открытие взаимодействия беспорядка и флуктуаций в физических системах от атомных до планетарных масштабов». Паризи обнаружил скрытые закономерности в неупорядоченных сложных материалах. Его открытия являются одним из наиболее важных вкладов в теорию сложных систем. Он доказал, что в спиновых стеклах равновесие никогда не достигается, так как фрустрации не позволяют удовлетворить всем ограничениям. В действительности существует бесконечное множество практически равновесных состояний, в которых фрустрации стремятся к минимуму. Исследования Паризи развиваются по 14 различным научным направлениям.
\end{abstract}

Ключевые слова: сложные физические системы; взаимодействие беспорядка и флуктуаций; лауреат Нобелевской премии по физике 2021 года Джорджо Паризи.

Для цитирования: Tyutyunnik VM. Disorder and fluctuations in complex physical systems: Nobel Prize winner in physics 2021 Giorgio Parisi. Journal of Advanced Materials and Technologies. 2021;6(4):243-246. DOI: 10.17277/jamt.2021.04.pp.243-246 


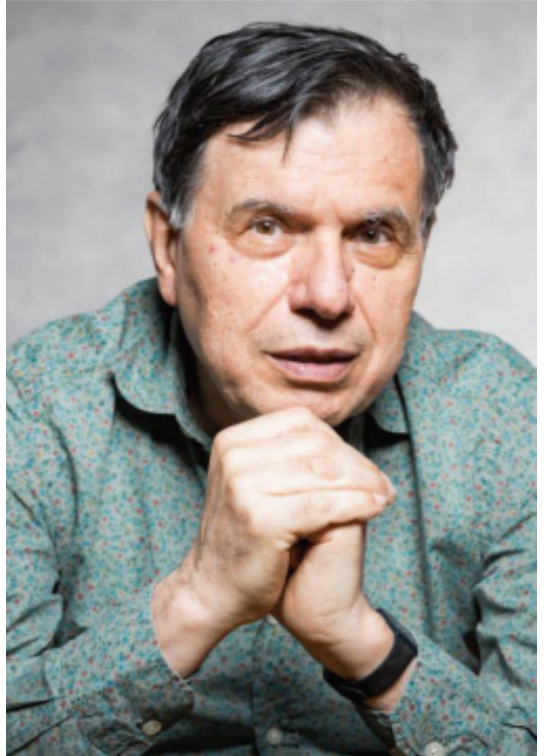

Giorgio Parisi

Giorgio Parisi, a physicist from the Sapienza University of Rome (Sapienza - Università di Roma) received half the prize money of the 2021 Nobel Prize in physics "for the discovery of the interplay of disorder and fluctuations in physical systems from atomic to planetary scales". The second half was divided between a Japanese professor working at Princeton University (USA), Shukuro Manabe (born 09.21.1931) and a German scientist from the Max Planck Institute in Hamburg Klaus Hasselmann (born 04.25.1931) "for the physical modeling of Earth's climate, quantifying variability and reliably predicting global warming" [1]. At first glance, unrelated areas of research of the laureates are nevertheless united by a single object - complex physical systems.

The press release from the Royal Swedish Academy of Sciences on October 5, 2021, says: “Around 1980, Giorgio Parisi discovered hidden patterns in disordered complex materials. His discoveries are among the most important contributions to the theory of complex systems. They make it possible to understand and describe many different and apparently entirely random materials and phenomena, not only in physics but also in other, very different areas, such as mathematics, biology, neuroscience and machine learning" [2].

Giorgio Parisi was born on August 4, 1948 in Rome, where he still lives. In an interview with Laura Bonolis, published on his personal website, the scientist said: "At school I studied very well in all scientific subjects. From an early age I had a strong inclination to mathematics. Apparently, I learned to read numbers very early ... By the age of thirteen or fourteen I had learned the basics of differential and integral calculus. By the end of my first year at the university, I discovered amazing books, such as the famous course of theoretical physics by L.D. Landau and E.M. Lifshits. Most of my career I shifted between statistical mechanics and high-energy physics. In the end I came to physical laws in complex systems" (translated by me) [3].

Giorgio Parisi is an amazingly versatile scientist, the rarest modern polymath. In the list of his publications, more than 10 years ago, 14 different scientific directions were highlighted, in which he achieved serious results. In 2008, this list contained 527 publications (including 4 monographs) [4] and about 700 scientific articles. In 2021, Giorgio Parisi became one of the three most cited physicists in the world (after A.Yu. Kitaev and M. Newman from the USA).

For many decades, prominent scientists of the world have been triying to advance in understanding how complex order arises from simple disorder, from chaos. Nobel laureates I.R. Prigozhin, M. Gell-Mann, G.t'Hooft, W.A. Fowler, A.H. Zewail succeeded. Significant progress in understanding this was achieved in the works of G. Parisi. The system that has attracted his attention since 1979 is called spin glass. Spin is a proper angular momentum of any elementary particle, and glass is a typical amorphous substance. The combination of these two completely different terms indicates materials in which individual atoms of a magnetic substance, for example, iron or nickel, are added to non-magnetic atoms (from 0.1 to $10 \%$ ) (Fig. 1).

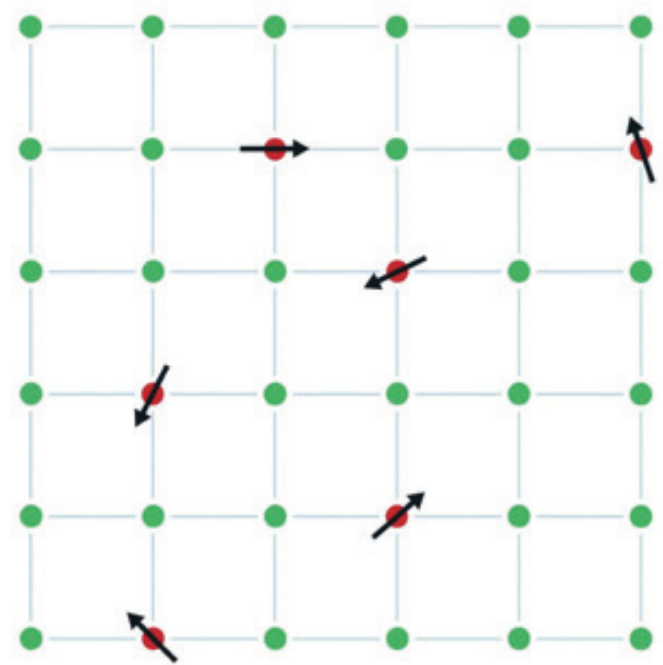

Fig. 1. Model structure of spin glass: iron atoms (red) are randomly incorporated into an ordered lattice of copper atoms (green) and randomly choose the directions of the spins (arrows) [12] 
In such a system, frustration occurs: triangles of atoms, in which each atom with each other tries to line up in opposite directions, but this is impossible. The challenge is to figure out how the spin magnets will end up. G. Parisi assumed that equilibrium is never achieved in spin glasses, because frustrations do not allow all limitations to be satisfied. In reality, there are an infinite number of practically equilibrium states in which frustrations tend to a minimum. The scholar suggested and proved that all such almost equilibrium states are similar to each other, have a hidden structure (order) and look chaotic only at first glance. He mathematically described what happens when order and chaos act simultaneously on the system [13]. This theory of G. Parisi was verified experimentally using a model based on random lasers and is now the basis in the theory of complex systems.

Disordered systems arise not only in magnetic alloys; therefore, conclusions from the study of spin glasses have spread to other areas - information retrieval systems, neural networks, spintronics, and even to wildlife. G. Parisi made breakthrough discoveries in quantum chronodynamics - the most complex system of interaction of quarks, for which he proposed mathematics as for complex disordered systems.

"The Nobel Prize winners in physics have proved that, without a doubt, the physical world is a single ocean of energy that appears and disappears after milliseconds, pulsating again and again. There is nothing solid and solid. This is the world of quantum physics" (translated by me) [14].

It is noteworthy to add that this year the forecast of Clarivate Analytics, which owns one of the largest research databases Web of Science, came true. From a database containing 52 million scientific articles published after 1970, experts selected 6500 most cited (2000 and more citations) works, which were included in the first three publications of G. Parisi. This was one of the rare occasions when scientometric results matched the opinion of nominators and scientists from the Royal Swedish Academy of Sciences.

This research was not supported by any external funding source.

The author declares that he has no known competing financial interests or personal relationships that could have appeared to influence the work reported in this paper.

\section{References}

1. Nobel Prize in Physics 2021. Available from: https://www.nobelprize.org/prizes/physics/2021/summary/ [Accessed 28 September 2021]

2. Press Release, 5 Oct. 2021: The Nobel Prize in Physics 2021. Available from: https://www.nobelprize.org/ prizes/physics/2021/press-release/ [Accessed 5 October 2021]

3. Bonolis L. Giorgio Parisi. Available from: https://chimera.roma1.infn.it/GIORGIO/interviews.html [Accessed 15 September 2021]

4. Parisi G. List of Publications. October 2008. Available from: https://chimera.romal.infn.it/GIORGIO/ papers.html [Accessed 15 September 2021]

5. Tyutyunnik VM. Graphene breakthrough into future technology: the 2010 Nobel Prize in Physics Laureate Sir Konstantin Sergeevich Novoselov. Journal of Advanced Materials and Technologies. 2021;6(1):6-9. DOI:10.17277/jamt.2021.01.pp.006-009

6. Tyutyunnik VM. Generation of high-intensity ultra-short optical pulses: 2018 Nobel Prize winners in Physics Gerard Mourou and Donna Strickland. Journal of Advanced Materials and Technologies. 2021;6(2):87-90. DOI:10.17277/jamt.2021.02.pp.087-090

7. Tyutyunnik VM. Another breakthrough in power supply technology - lithium-ion batteries: 2019 Nobel Prize winners in Chemistry John Goodenough, Stanley Whittingham and Akira Yodhino. Journal of Advanced Materials and Technologies. 2021;6(3):163-166. DOI:10.17277/jamt.2021.03.pp.163-166.

8. Tyutyunnik VM. Nominations for the Nobel Prize in Physics in 1911-1950. Inzhenernaya fizika=Engineering physics. 2021;2:10-33. DOI:10.25791/infizik.2.2021.1189. (In Russ.).

9. Prospective areas of research in science and technology: Collective monograph. Ed. Prof. V.M. Tyutyunnik. Foreword: D. Shechtman, I. Hargittai. Tambov, Moscow, St. Petersburg, Baku, Vienna, Hamburg, Stockholm, Bouake, Varna, Tashkent: INIC Publ. House "Nobelistics"; 2021. 242 p. DOI:10.52529/ 9785866092437

10. Tyutyunnik VM. Nobel laureates - domestic and foreign members and award winners of the Russian Academy of Sciences. Istoriya nauki $i$ tekhniki $=$ History of science and technology. 2020;9:3-26. DOI:10.25791/ intstg.09.2020.1210. (In Russ.).

11. Tyutyunnik VM. Science, Technology, Society and International Nobel Movement. Proceedings of the Nobel Congress - 12th International Meeting-Conference of Nobel Prize Winners and nobelists, 2-5 Oct. 2019, Tambov (Russia). Tambov, Moscow, St. Petersburg, Baku, Vienna, Hamburg, Stockholm, Bouake, Varna, Tashkent: INIC Publ. House "Nobelistics"; 2019. 256 p.

12. The Nobel Prize in Physics 2021: Popular Science Background. Available from: https://www. nobelprize.org/uploads/2021/10/popular-physicsprize2021. pdf [Accessed 15 September 2021] 
13. Mézard M, Parisi G, Virasoro MA. Spin Glass Theory and Beyond. NJ USA: World Scientific, Teaneck; 1987. $476 \mathrm{p}$
14. Assaraf J. Available from: https://vk.com/@81321249-laureaty-nobelevskoi-premii-v-oblasti-fizikidokazali-chto-v [Accessed 1 November 2018] (In Russ.).

\section{Информация об авторах / Information about the authors}

Тютюнник Вячеслав Михайлович, доктор технических наук, профессор, ФГБОУ ВО «Тамбовский государственный технический университет»; генеральный директор, Международный Информационный Нобелевский Центр, Тамбов, Российская Федерация; ORCID 0000-0002-2099-5730; e-mail: vmtyutyunnik@gmail.com
Vyacheslav M. Tyutyunnik, D. Sc. (Engineering), Professor, Tambov State Technical University; Director General, International Nobel Information Centre, Tambov, Russian Federation; ORCID 0000-0002-20995730; e-mail: vmtyutyunnik@gmail.com

Received 28 October 2021; Accepted 11 November 2021; Published 28 December 2021 